\title{
Digital Transformation in Communities of Africa
}

Fouad A. Kazim, Merchanfeeling.co, France \& Trendfeeling LTD., USA

iD https://orcid.org/0000-0003-1730-4038

\begin{abstract}
This paper synthesises, categorises, and provides clarity on the African continent's digital transformation (DT) programs that align with the United Nations development initiatives and Africa's Agenda 2063 and its subprograms. It provides that analysis is needed to understand the digital landscape across the continent for those interested in FDI opportunities and other social enterprises looking to impact all aspects of African socioeconomic digital development. The author believes this paper is relevant for understanding the challenges and opportunities of the current and future areas of the African digital ecosystem.
\end{abstract}

\section{KEYWORDS}

African Socioeconomic, Information and Communications Technology, Digital Development, Digital Technologies Entrepreneurship, Information Technology

\section{INTRODUCTION}

A new generation of youthful 'digital natives' is growing across Africa and set to fuel growth and drive adoption of new digital technologies services geared to impact all areas of African society, empowering lives, transforming businesses, and increasing engagement, equitability, and wellbeing — impacting all the continent's cities, towns, and villages. The challenge of degree of heterogeneity and differences in growth models across these emerging economies is significant for growth as countries are not starting from the same base. To revive economic growth and job creation in Africa, international research institutions such as the World Bank (WB), United Nations (UN), International Monetary Fund (IMF), Organisation for Economic Co-operation and Development (OECD), World Economic Forum (WEF), and European Commission (EC) have focused their attention on the growth of digitisation in industry and enterprises (African Development Bank [AfDB] et al., 2017; Arntz, Gregory, \& Zierahn, 2016; European Economic and Social Committee, 2017; OECD, 2017; WEF, 2016). Such institutions define digitisation as the mass adoption of connected digital services by consumers, enterprises, and governments (AfDB et al., 2017; OECD, 2017; WEF, 2016).

Empirical work undertaken across the African Union (AU) highlights vision priority areas as covering economic growth, sustainable development, employment, and wellbeing for people and communities, with initiatives being developed for the broader and long-term AU Agenda 2063, forming the first of the 10-year incremental phasing strategies using technologies to impact critical sectors of, among others, agriculture, energy, environment, health, infrastructure development, mining, security, and water (OECD, 2017; WEF, 2016; WB, 2019a).

This empirical investigation combining the role that selected digital technologies play in overcoming social and economic challenges is presented and discussed. The aim is to contribute

\section{DOI: $10.4018 /$ IJDSGBT.287100}

This article published as an Open Access article distributed under the terms of the Creative Commons Attribution License (http://creativecommons.org/licenses/by/4.0/) which permits unrestricted use, distribution, and production in any medium, provided the author of the original work and original publication source are properly credited. 
towards advancing relevant knowledge and recommendations for the future on the theoretical direction of digital transformation (DT) in African economies and communities. The study's objectives were to explore policies and programs aimed at enabling African countries and communities to adopt ways to improve socioeconomic development performance and communities' prosperity by enhancing digital technologies. The question asked is whether African countries can take advantage of programs such as those implemented in other emerging economies of East Asia like India, Korea, and Singapore. The primary objective was to assess the ability of current frameworks, such as those proposed by the G7 and G20, to deliver the potential of DT to increase trade and economic growth, bridge inequalities in African countries, and further enhance rural communities' growth (Department of International Relations and Cooperation, 2019; WB, 2019c). Specifically, objectives centered on:

1. reviewing demographic and economic opportunities and challenges and assessing their implications for attainment of the continent's digital development aspirations (Tor, 2017);

2. using digital development methodology, frameworks, and roadmaps to benchmark achievement; and

3. examining African ICT liberalization and the role of facilitating governments.

\section{METHODOLOGY AND DATA COMPILATION}

The study reviewed 1468 documents over six months — primary literature, secondary analysis of data, identification of policies, briefings, and notes, and a comparison of emerging market country frameworks on DT implementation. The study used international policy documents, briefings, working papers, frameworks, and roadmaps of actions used by the AU, United Nations Economic Commission for Africa (UNECA) agencies, WB, OECD, WEF, Institute for Security Studies (ISS), World Summit on the Information Society (WSIS), and International Telecommunication Union (ITU) obtainable across search engines, specialist database, Government and non-governmental agencies across African countries, EU, USA.

Specific documents used were those aligned with Digital Africa's broader goals 2030-63 and initiatives to achieve these digital strategies and programmes for transformation as shown in Annex A1, Annex A2.

The purpose was to review those primary documents on digital technology developments for short-to-long-term aspirations, applications, and contributions within and across sectors. These reviews helped to identify key digital development challenges and opportunities, explore potential solutions, and assess how the frameworks align with countries' ability to attain digital development aspirations. The frameworks, roadmaps, and guidance documents put into practice the following scenario: OECD's Going Digital projects, with integration policy frameworks across seven building blocks (access, use, innovation, trust, jobs, society and market openness) and supported by quantitative indicators and practical policy guidance. The synthesized data bring together the policies African governments must consider in order first shape and achieve a common African digital.

\section{MAIN ECONOMIC CHALLENGES FACING AFRICA}

Africa's population is the fastest growing in the world Bar Chart 1. Population growth rate in Africa 2020-2050. It is expected to increase by approximately 50\% over the next 18 years, from 1.2 billion people to over 2.15 billion by 2035-2050 (AfDB, 2014,). A forecasted $0.10 \%$ declining trend from benchmark year 2020 .

From a socioeconomic perspective, population growth constituting working-age individuals (aged 15 to 24) is crucial in regional development (fig1) and has potential for the continent's overall economic wellbeing. 


\section{Main Economic Challenges Facing Africa}

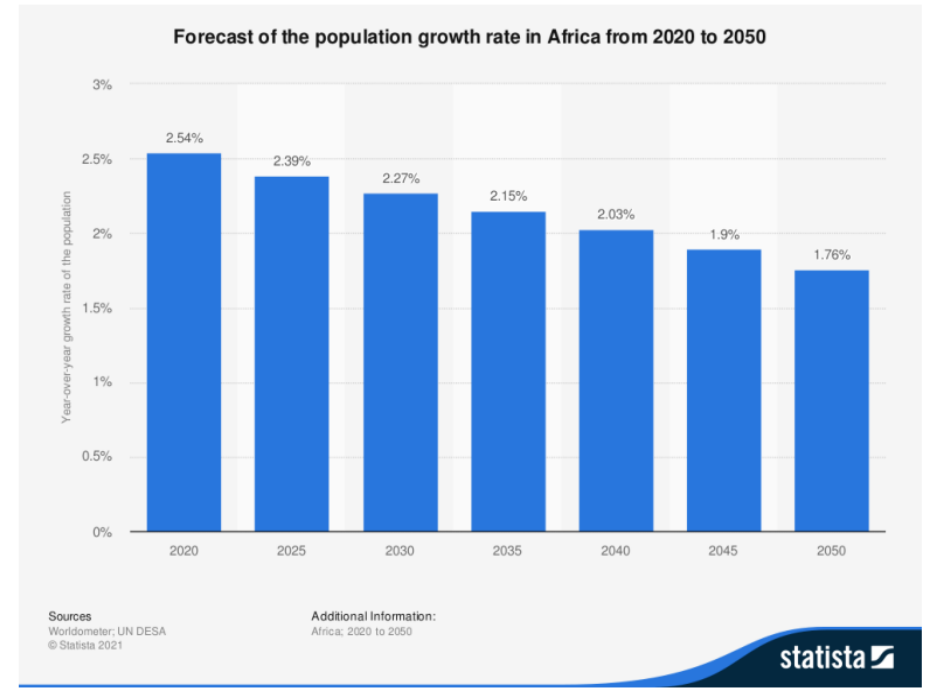

Notes: Figure. 2 shows answers to the survey question, "Which of the following areas of digitalisation do you think should be the priorities for regional and continental co-operation to help

Figure 2. Data source: United Nations(2013)World Population Prospects.

\section{Main Economic Challenges Facing Africa}

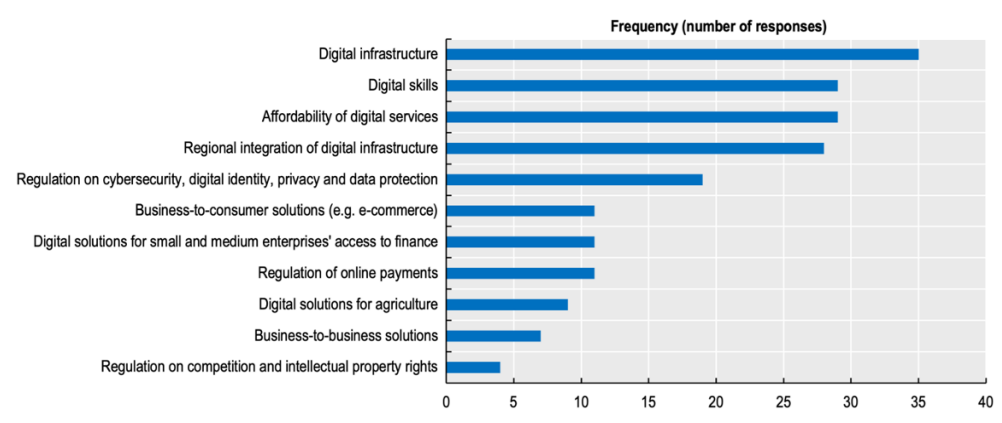


create more and better jobs in your region?". It is based on responses from six (out of Africa's eight) Regional Economic Communities and on individual assessment on 23 African countries. Respondent to the survey included policy makers, experts on digitalisation and representatives of private companies working in Africa's telecom and digital activities. For this question, each respondent was asked to select five top priority areas out of an open-ended list of 15 areas, with an option to add any additional areas of their choice.

AU governments are working with technology partner organizations across the region to solve challenges not in employment, education or training (NEET), including health a contributor to easing financial burdens for young working adults (aged 15 to 29), and prioritizing eight pillars to diminish social risks and lack of employment opportunities and increase technology skills and public expenditure.

The related action areas, discussed in dedicated sections below, are: employment and entrepreneurship; education and skills development; gender, health, and wellbeing (excluding family planning); rights, governance, and youth empowerment; agriculture, climate change, and the environment; and telecommunication and infrastructure these form the broader discussion areas of Main Economic Challenges Facing Africa.

Governments faced with socioeconomic challenges, widespread unemployment, and political marginalization see the need to invest in the working-age group for job creation (AUC, 2017; AUC/ OECD, 2020; Arnould \& Strazzari, 2017). The WEF and the International Trade Centre (ITC), a community of business leaders and experts, have identified areas for consideration, ranging from refreshing policies and expanding connectivity to upgrading logistics and managing data. Each area comes with a goal and recommended steps (ITC and WEF, 2019).

\section{E-Employment and E-Entrepreneurship}

\section{The Employment Landscape}

The African labor force is projected to expand by more than 14 million per year. Economic growth rates post-pandemic are forecast to fall sharply from $2.4 \%$ in 2019 to -2.1 to $-5.1 \%$ in 2020 , marking the first recession in the region over the last 25 years (WB, 2020a). Recent epidemics have also slowed youth employment and education, lowering the potential to create enough quality jobs against the tide of this fast-growing labor force.

E-Employment - Cases on digital initiatives for access (Internet, e-mail) to increase employability and alleviate unemployment through e-networking with recruitment agencies government agencies, and businesses, thus enabling job creation, include Mauritius' e-Recruitment System allowing citizens to apply for a post not only from a personal computer but also through their smartphones (Gürtzgen, Nolte \& Pohlan et.al, 2018). The development of this portal serves in advancing progress in SDGs 8, 9, and 17. In Nigeria, the Nigerian Postal Service initiated the project NIPOST Address Verification System, establishing a platform that can create hundreds of thousands of sustainable jobs. Any qualified individual with a smartphone, Internet access, and NIPOST Address Verification System agent app can join the community and get a paying job (SDGs 1, 2, 5, 8, 10, 11, and 16). In South Africa, the Department of Public Service and Administration has officially launched the government's e-recruitment system enabling job seekers to apply for positions in public service through an online platform (SDGs 8, 9, and 17). In Rwanda, Job in Rwanda Ltd. developed an online recruitment portal connecting skills and facilitating recruitment operations between employers and candidates (SDGs 8, 9, and 17). DIGIFY AFRICA, for employment-oriented skills training in Ghana, provides digital skills training to youth and entrepreneurs looking to enter the marketing industry or grow their businesses through online and in-person courses. It boasts a strong alumni network of over 75,000 individuals as well as more than 40 agency partners to produce digital campaigns, content, and services. It has seen over 500 new professional careers since its inception in 2014 (International Finance Corporation [IFC], 2019). 


\section{E-Employment and E-Entrepreneurship}

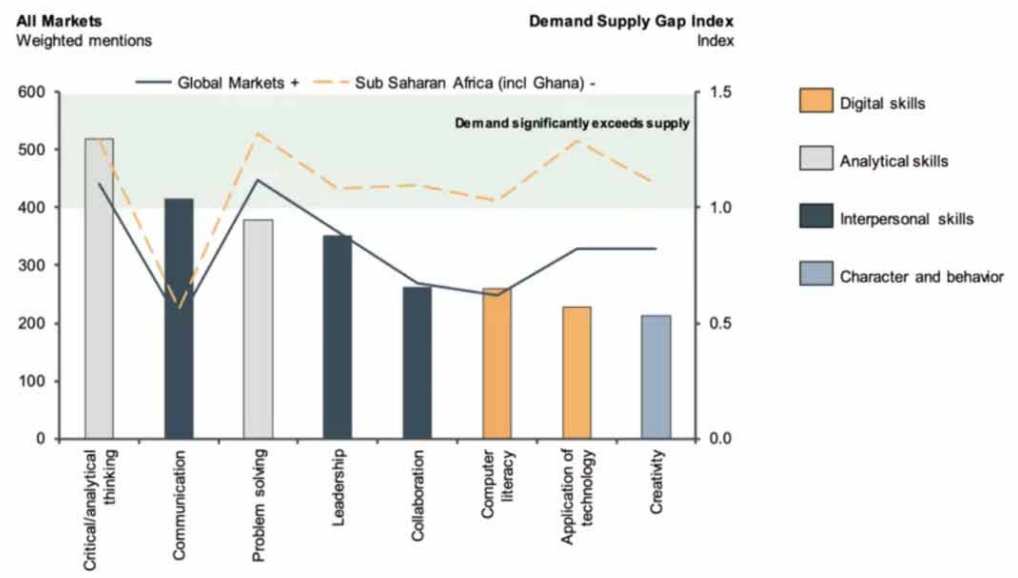

\section{The Entrepreneurial Landscape}

Twenty-two percent of Africa's working-age population are starting businesses concentrated within a limited number of sectors. Activities include retail (64\%) and the hotel and restaurant trade (97\%). The retail sector has low-growth businesses, with 54\% employing only the business owner (Guislain, 2018; Herrington \& Kew, 2016). Africa's female entrepreneurship rate is the highest in the world; $27 \%$ of the female adult population is engaged in early-stage entrepreneurial activity. Small and medium enterprises are now the biggest formal employers in sub-Saharan Africa (SSA) and key in creating 54 million jobs across the continent by 2022. An additional consideration is that Africa has the highest small business discontinuance rate (Herrington \& Kew, 2016, 2017).

Digital technologies are transforming traditional jobs and creating new forms of work (International Labour Organization, 2018). Large companies are increasingly contracting smaller firms in other countries to perform entire business processes and functions. A growing number of workers are also engaging in microwork, working online to complete a series of small, less skillintensive tasks through platforms such as Amazon Mechanical Turk and Figure Eight (WB, 2015).

E-Entrepreneurship - The United Nations Conference on Trade and Development (UNCTAD) demonstrated the business-to-consumer e-commerce market in Africa as worth about $\$ 5.7$ billion in 2017, representing less than $0.5 \%$ of the continent's GDP — far below the world average of over 4\%. Increasing e-business platform initiatives have been developed and range from those with focus markets, like Angola's Barb Look web platform for barbershops and clients to choose which service they want, to a Burundi-based East African Community e-marketplace that is an east African online distribution center for connecting small businesses and rural communities to local, regional, and international markets online (SDGs 1, 3, 5, 8, 9, 10, 12, and 17). Another country case is Cote d'Ivoire's TaxiJet, the first Ivoirian taxi booking platform. In Tunisia, two major government initiatives encourage Tunisian companies to use ICTs to increase their productivity and created specialized research centers 
and technology parks to strengthen the existing synergy between educational institutions and the private sector. In Nigeria, the Postal Service launched the NIPOST Electronic Stamp, developing a one-of-a-kind electronic stamp called QuBit that can meet the current day's needs and denote business challenges. With its new electronic stamp, over 61 million Nigerians will be engaged, some 113,000 jobs created directly and indirectly, and a user-friendly experience established with NIPOST. This project assists in advancing SDGs 1, 2, 8, 9, and 17. Also in Rwanda, Tap \& Go (a product of AC Group Ltd), is being used in Kigali and Yaoundé, with over 670,000 users daily. The project is carried out in partnership with the WEF, Government of Rwanda, Kigali Bus Services, Rwanda Federation of Transport Cooperatives, Royal Express, Government of Cameroon, STECY, DMM.com, and Transform Africa, and it relates to SDGs 8, 9, 11, and 17. Additionally, in an effort to reduce corruption, improve transparency and efficiency, and minimize potential collusion among bidders, Rwanda has established electronic government procurement systems known as Umисуo, meaning "transparency" in the local language. Uтисуo, a web-based e-procurement system, was developed as part of a WB-funded public-sector reform program for better government-to-business results. The system is open to all, meeting SDGs 1, 8, 9, and 16. In Uganda, Bizcust is a mobile webbased application system for expanding the customer, market, and transport accessibility base for businessmen and farmers. Bizcust runs on all mobile devices and computers. The problem it targets resides in the fact that farmers lack information on updated commodity prices offered by different agro-businessmen. This project is therefore extremely useful as it relates to poverty, food security, and gender equality issues (SDGs 1, 2, and 5). Kenya M-PESA makes domestic payments easy. Started in 2007, it now boasts 30 million users in 10 countries, with other competitors such as MTN Money, Orange Money, and Airtel money also operating around the continent. M-PESA services are now offered in countries as diverse as Albania, D.R. Congo, Egypt, Ghana, India, Kenya, Lesotho, Mozambique, Romania, and Tanzania. This initiative assists in advancing all 17 SDGs (GSMA, 2019; UNECA, 2019). Similarly, financial technology ("fintech") has also expanded across Africa over the past years: $21 \%$ of adults in Africa now have a mobile money account, with numbers having doubled since 2014, the highest of any region globally (Demirgüç-Kunt et al., 2018). Digital technology can also spearhead employment, as a recent WB report on the future of work in Africa points out (Choi et al., 2019). Jobs directly attributed to the mobile economy lay at 1.1 million and were projected to reach 1.3 million in 2020, with an additional 2 million indirect jobs (GSMA, 2017).

\section{E-Education and E-Skills}

\section{The Digital Education and Skills Landscape}

Structural problems affecting education systems continue to be a stumbling block in the African group of countries' efforts to stimulate sustainable entrepreneurial activity and improve business productivity. The Continental Education Strategy for Africa (CESA) (AU, 2015) aims to transform education systems commensurate with the wider vision of increased ICTs and digital skills for economic growth and business. CESA has moved to incorporate ICTs, digital tools, and massive open online courses (MOOCs) as possible solutions (AU, 2015). This section provides a clear relationship between the level of education and the likelihood of business owners' success indicating growth expectations within a business. The disparity in education indicates that $65 \%$ of low-growth business operators only have a primary school education while $80 \%$ of high-growth businesses have completed secondary, post-secondary, or tertiary education. To alleviate shortfalls in education infrastructure, investments, standards, and skill development, the AU envisioned a 10-year continental education strategy 2063 Agenda roadmap to realize the knowledge, competences, skills, innovation, and creativity for core African values and promote sustainable development at national, sub-regional, and continent levels to "create a new African citizen" who will be an effective change agent (AU, 2015; Global Education Monitoring Report Team, 2017).

As partner initiatives, HP's Learning Initiative for Entrepreneurs (HP LIFE) and the Be Online program offer two unique online digital learning platforms presented to support education, 
employment, engagement, and entrepreneurship. The aims are to enable better learning outcomes for 100 million people by 2025 and add 1 million users between 2016 and 2025 - a commitment that aligns with the AU's CESA. The CESA 16-25 guiding principles, pillars, and objectives are geared to fulfil Aspiration 6 of the Agenda 2016 vision to build on education policy to provide vocational training and science, technology, and innovation actions underpinned by communication and governance to give stakeholders and actors the freedom to act and realize initiatives (Mundy et al., 2017; Tikly, 2019).

Additional actions include the Science, Technology and Innovation Strategy for Africa (STISA - 2024) initiatives, which use learning technologies to impact education technology and e-learning opportunities, and the Continental Strategy for Technical, Vocational Education and Education (TVET), to support economic development and the creation of national wealth and contribute to poverty reduction. It is necessary for each country to formulate a national TVET policy and establish a national training coordination structure and implementation bodies that will be able to manage the TVET policy and entire system. Actions to develop higher-level skills in technology and innovation are paramount for transforming national production systems and industrializing African economies (Kanwar et al., 2019).

African ministers of education and training helped articulate Africa's post-2015 education agenda submitted to and endorsed by the WEF and organized by UNESCO 2015, providing an additional 10 priority areas for the region: equitable and inclusive access for all; inclusion, equity, and gender equality; teachers and teaching; education quality and learning outcomes; science, technology, and skills development; education for sustainable development and global citizenship education; youth and adult literacy; skills and competencies for life and work; financing, governance, and partnerships; and education in crisis situations (AU, 2015).

E-Learning - Digital technologies, especially the possibility of online learning, offer the potential to vastly expand access to postsecondary education. From 2008 to 2018, about 15,000 new education apps and online technologies were created, accelerating the widespread adoption of digital education (AU, 2020). The World Bank's NESAP-ICT program has been trying to help countries with their online learning challenges. The New Economy Skills for Africa Program - ICT was launched in 2008 to support SSA countries in building skills for the knowledge economy (IFC, 2019). Case examples reveal digital learning initiatives to provide business and IT skills training free of charge to people and online communities offering more than 30 self-paced courses designed to help users develop business and IT skills in their own time and at their own pace (AU, 2020).

MOOCs, formal global network learning environments, provide partnered learning and connect learners, teachers, and communities in new ways of learning (Starke-Meyerring, 2010). With World Bank support, a new pilot initiative in Tanzania helps employers overcome the mismatch of skills in the local labor market and seeks to incorporate Coursera offerings as part of a broader initiative to help equip students with market-relevant IT skills. In Tanzania, NESAP-ICT is helping to support so-called SMART (Software, Mobile Applications, Research and Technology) skills development. A conference in Mauritius addressed new developments and outcomes of the United Nations Development Programme (UNDP) Millennium Development Goals representing Blackboard as a development opportunity to enhance e-learning for young adults. Another contributor covering local needs is Open University e-learning, an inspiration to certain African education authorities (Betchoo, 2017). In Ghana, to tackle the low number of African women in tech, Ivy Barley founded Developers in Vogue, an all-girls coding training program. Other examples programs contributing to women and girls in digital skill and literacy include.

Source: EU/Consiel Santé Digital4Women.

\section{Gender, Health, and Wellbeing (Excluding Family Planning)}

Reductions in armed conflicts have realized improvements in health, poverty, and living standards and increased access to communal education (OECD, 2018; UNDP, 2017). Yet, Africa's poverty 


\begin{tabular}{|c|c|c|}
\hline \multicolumn{3}{|c|}{ E-Education and E-Skills } \\
\hline Initiative & Country & Description \\
\hline SheSecures ${ }^{144}$ & Nigeria & $\begin{array}{l}\text { She Secures is an organisation based in Nigeria, for women professionals and } \\
\text { enthusiasts in cyber security. They build awareness in cyber security and } \\
\text { information security for women and girls of all ages. }\end{array}$ \\
\hline $\begin{array}{l}\text { Fempower } \\
\text { Africa } a^{145}\end{array}$ & Across SSA & $\begin{array}{l}\text { Fempower Africa is a social enterprise that seeks to train, teach and equip } \\
\text { women in Africa with technology skills, leadership skills and entrepreneurship } \\
\text { skills. Fempower Initiative Africa supports, inspires and empowers female } \\
\text { founders both online and offline. }\end{array}$ \\
\hline $\begin{array}{l}\text { Coding for } \\
\text { Employment } \\
\text { Platform }^{146}\end{array}$ & Across SSA & $\begin{array}{l}\text { The African Development Bank and technology firm Microsoft launched in } \\
2019 \text { the Coding for Employment Platform, an online tool to provide digital } \\
\text { skills to African youth, wherever they are across the continent. }\end{array}$ \\
\hline $\begin{array}{l}\text { The Virtual } \\
\text { University of } \\
\text { Senegal }^{147}\end{array}$ & Senegal & $\begin{array}{l}\text { The Virtual University of Senegal is the first public digital university in Africa, } \\
\text { founded in } 2013 \text {, combining e-learning with presence-based tutorials and } \\
\text { networking. The e-learning platerom and the laptops with mobile Internet } \\
\text { connection provided by the University grant students a maximum of flexibility, } \\
\text { which allows (self-) employed students, women with children, students living in } \\
\text { rural areas and/or far from the capital to access higher education. }\end{array}$ \\
\hline $\begin{array}{l}\text { African Girls } \\
\text { Can Code } \\
\text { Initiative }^{148}\end{array}$ & Across SSA & $\begin{array}{l}\text { In collaboration with the African Union Commission, ITU and UN Women } \\
\text { launched the African Girls Can Code Initiative (AGCCI) } 2018-2022 \text {, which } \\
\text { consists of a four-year programme to train and empower girls aged } 17 \text { to } 20 \\
\text { years old with ICT skills. }\end{array}$ \\
\hline
\end{tabular}

level remains very high and the region is one of the most unequal in the world - 10 of its countries are listed among the 19 most unequal in the world. World Bank initiatives to expand opportunities that empower women include focus on legal rights and economic opportunities (Hallward-Driemeier and Hasan, 2012) to strengthen incentives and abilities to pursue property rights through policy, law and regulations and ensure enforcement through the Women's Legal and Economic Empowerment Database for Africa (Women-LEED-Africa). The new database provides detailed indicators and links to statutes, constitutions, and international conventions on issues of legal capacity, marital property, land ownership, and labor law.

GSMA (2017) indicated that mobile phone ownership and usage (34\%) represent a barrier for women, with higher hurdles to gaining access and meaningful use for women and girls with low education and low income. For example, Nigerian women (45\%) who do not own a mobile phone reported literacy as a key barrier. Initiatives in place aim to increase the level of services being accessed; only about $25 \%$ of African women aged 15 and above had access to a formal financial account, compared to almost 33\% of men (Demirgüç-Kunt et al., 2015). In South Africa, women are less generally likely than men to make mobile phone-enabled transactions, despite having formal financial accounts (OECD, 2018). Previous studies explain these gaps as related to social and cultural perceptions, with main contributors arguing that women are more likely to reject mobile banking since they are affected by social norms (peer influence) to a greater extent than men (see Garbarino and Strahilevitz, 2004; Laukkanen and Pasanen, 2008; Riquelme and Rios, 2010).

The Internet and digital platforms can help foster social wellbeing through connecting people and ideas, innovation, and relevant knowledge sharing, including relevant technologies and helping women access health care-related information, medical treatments, or prophylaxis, and reduce the risks and costs of early pregnancy (Billari, Ginutella and Stella, 2017). Moreover, mobile phones allow women to access relevant information, including on governmental support, election access, and pension rights (GSMA, 2013, 2016). Mobile phones enable digital access to help the collection of relevant data that could complement socioeconomic statistics needed to improve services. A survey of Kenyan women found M-PESA mobile banking accounts saw over three quarters of transactions occurring at least twice a week, with $95 \%$ indicating they sent money to their relatives. Women users (37\%) owned a business, and 96\% indicated M-PESA helped them scale their venture (Dubus and van Hove, 2017). As a result, an estimated 194000 households have saved money more effectively and moved out of extreme poverty (Gates Foundation, 2017). 
The Mobile Alliance for Maternal Action (MAMA) uses mobile phones in partnership with Vodacom Foundation to deliver vital health information to new and expectant mothers, supporting programmes in Africa, Bangladesh and India. Digital tools are designed with women's specific needs and priorities in mind, making them more likely to be used by women and to encourage women to use other online services (Cummings \& O'Neil, 2015, p. 6). Unlocking the benefits of the DT can therefore transform the lives of many and offer leapfrog opportunities to women and girls in particular. Technologies used for connecting digital health and e-health services, social care, and wellness sectors offer solutions across the continent. In Kenya, mobile health technology is used to improve antiretroviral medication compliance by $11 \%$. In Botswana, the deployment of a mobile-enabled programme reduced government response time to malaria outbreaks from four months to three minutes. Delivery of information and awareness via text message to young pregnant mothers in Mali helped to reduce perinatal and maternal mortality by $30 \%$ (OECD, 2018). Additional programs being deployed through sponsors' accelerator partners are examples of pharmaceutical multinationals providing mentoring and financial support to e-health start-ups in Africa. In Morocco, the Ministry of Health is implementing a promising pilot project to ensure better access to care for people in landlocked regions through the gradual deployment of telemedicine units in 160 isolated municipalities, representing $6.25 \%$ of the population by 2025. In Algeria, AQUINETIC offers solutions to visualize data on rare diseases data, AHMINI in Tunisia provides a simplified subscription to health insurance for rural women via mobile phone, and SUSU in Côte d'Ivoire is a platform offering healthcare packages to African diaspora upon repatriation. The Tanzanian Training Centre for International Health uses an audio teleconferencing model and an online e-learning platform to teach health workers and nurses about maternal and perinatal health care in rural areas (Stroetmann, 2018, 2019).

\section{Rights, Governance, and Youth Empowerment}

\section{Rights and Governance}

SDG 8 indicates key features of what constitutes a successful society and a vibrant African economy incorporating digital technology to improve life, wellbeing, and health, requiring grounded policies and approaches to include such values as human rights (SDG 8 targets) and for equity. Mobile-enabled digital ID tech identifies individuals through channels used in many areas related to registration, through digitalizing ID and using biometrics (fingerprint, iris, facial recognition, etc.) (AU, 2019). The benefits of a legal identity include gender equality, social protection delivery, financial inclusion, improved governance, safer migration, superior health delivery, enhanced and refugee child protection, reducing statelessness, and better access to land and property rights aligning with the UN Legal Identity Agenda 2020-2030 (Hanmer and Elefante, 2019; United Nations Legal Identity Agenda Task Force, 2020). Take up and usage must be enhanced by low cost, ease of use, and scalability (UNDP, 2017; WB, 2019c; WEF, 2020). Governance must promote joint action for e-services, e-transactions, data protection and privacy, cybercrime and consumer protection, health and non-health sectors, public and private actors, and citizens toward common interest and working to achieve DPP, OECD, UNDP and WEF policies and frameworks for Agenda 2063.

Governance/democratization focuses on outcome levels with emphasis on transparency, accountability, decision-making, and support for the rights of all citizens and empowerment across individual African countries and the continent. Governance policy at sector and cross-sector levels needs to be addressed to improve inequalities of gender and in communities (Hellström, 2010; Kaup Lapõnin, 2018). Reports indicate a few African countries have made progress in developing digital ID systems for legal ID and to exploit the digital economy. Given almost 25 years of ICT development on the continent, for many African countries' ICT readiness (infrastructure and access), use, and capability (skills) is still low but rising (AU, 2017; ITU, 2017).

Case examples of digital technology, ICT, and mobile initiatives include Kenya, based on partnerships, consultations with partner governments, policy, and implementation experiences with emphasis on mainstreaming and harmonization issues to emphasize civil society, donor agencies, 
and private sector/software developer contributions. Digital technology initiatives also consider ICT for all types of governance themes, such as the rule of law and anti-corruption for SDG initiatives (Auriacombe and Vyas-Doorgapersad, 2019).

\section{Youth Empowerment and Advocacy}

The Youth Inclusion Project, co-funded by the European Union and implemented by the OECD, supports African countries (Côte d'Ivoire, Ethiopia, Malawi, and Togo, amongst others) in better responding to the aspirations of young people and strengthening youth involvement in national development processes. A number of activities are carried out at the country level, including the publication of a youth wellbeing policy review, national workshops with key stakeholders to foster policy dialogue on youth inclusion, and training activities to strengthen the capacities of national policymakers in designing evidence-based policies that promote youth inclusion and wellbeing (OECD and Africa, 2015; AUC/OECD 2021).

The youth in Africa are far more active on social media and digital platforms than their older counterparts are. The rise of social movements also shows that young people may use other civic channels to act on what they care about (World Bank Group, 2018). Young women participate less in public affairs compared to their male counterparts and report significantly less interest in public affairs and discussions around them (Das and Espinoza, 2019). The Internet affords anonymity, allowing groups that would otherwise not have a voice to express themselves through online media. An example case in South Africa highlights a student-led Fees Must Fall movement; although young people may not participate in formal political processes, they are nevertheless politically very vibrant (Das and Espinoza 2019). Youth advocacy for empowerment can be used to address imbalances, inequities, and disparities, to promote human rights, social justice, and a healthy environment, and to further opportunities for democracy by promoting children's, youths', and women's participation using technologies such as email, websites, blogs, podcasts, text messages, Facebook, and Twitter to reach a large audience and enable fast communication (UNICEF, 2010).

\section{Agriculture, Climate Change, and the Environment}

\section{E-Agriculture}

In the area of agriculture, in-farm production and off-farm processes are projected to have continued growth with the potential of 41 million jobs over the next 10 years, uplifting low-skilled men and women farmers in rural communities and building connectivity to information and markets (AfDB, 2014; WB, 2019a). The Digital Development Partnership (WB, 2019d) is assisting with development of an economic framework to apply disruptive technologies in agriculture to enable farmers and agribusiness entrepreneurs to accelerate current methods to increase productivity, efficiency, and competitiveness, facilitating access to markets, improving nutritional outcomes, and enhancing resilience to climate change (WB, 2019b, AUC/OECD 2021).

Agri-tech solutions that increase competitiveness along the value chain and sustainability of agricultural transition range from mobile apps and solar applications to portable agriculture devices and biofortified foods, to sensors/IoT and blockchain in an evidence-based way (WB, 2019c). A toolkit developed jointly by the World Bank's Agriculture Global Practice and the Digital Development Global Practice serves as a blueprint for a new generation of digital agriculture lending projects (WB, 2019c). One example is an SMS network for farmers who are working with agricultural extension officers. The network allows many-to-many, mediated, conversations-a quantum improvement over the one-way communication of a government official telling farmers what to do.

In Ghana, agri-tech firms like Farmable, Farmerline, and Esoko have successfully pursued the creation of new business ventures and renewal of existing, matured corporate business models. Supporting farmers with pricing data, crowdfunding, and communication activities, these agri-tech firms are also connecting farmers with buyers and helping them determine what differentiates them 
from competitors. Digital technologies are playing a role in Nigeria's agricultural sector too. Prime Wave, an engineering company that supplies equipment to rice processing firms, and Al-Wabel Trading Company Ltd, a rice miller, have been collaborating to invent new technological solutions aimed at improving performance in rice processing. However, these firms have had to overcome regulatory and institutional challenges in the sector. Launched in 2014, Kenya's Twiga foods uses a technology platform to improve the supply chain from farmers to markets and serves around 2,000 outlets a day through a network of 13,000 farmers and 6,000 vendors. The company has reduced typical post-harvest losses in Kenya from 30\% to 4\% for produce brought to market on the Twiga network (WB, 2019b).

In Botswana, the Naledi Magowe initiative created the mobile agriculture app mAgri giving farmers access to information, markets, low-cost communication, and short-term finance (WSIS and ITU, 2018). mAgri allows farmers to market their products and services across the country, using any cell phone, and from any part of Botswana, advancing SDGs 1, 2, 6, and 8. In Chad, the Association of Technicians in Information and Communication Technology created a program providing farmers with ICTs, to aid them in gaining information on their activities (SDGs 1 and 2). The project's overall objectives are to: introduce agriculture to new devices for the use of ICT; sensitize and train young people on the challenges of rural and agricultural development in Chad through ICTs; and modernize the agricultural production system through ICTs to provide farmers with practical means for the progressive reduction of poverty and the digital divide. In March 2008, the Government of Ghana and the WB launched the West Africa Agriculture Productivity Program. One project under the Ministry of Food and Agriculture piloted an electronic extension of agriculture technical services to farmers and other stakeholders in the agriculture sector using a web portal, call centre facility, and interactive voice response system to assist farmers. This model is relevant to SDGs 1, 2, 3, 4, 5, 6, 7, 8, 12, 13, 14, and 16 (WSIS and ITU 2018.

\section{Climate Change and the Environment}

Reducing extreme weather events such as cyclones and heatwaves due to increased industrial emissions and deforestation increasing carbon dioxide requires climate change initiatives at international, national, regional, and local levels (UNICEF, 2019). WSIS and ITU (2018) provide several case examples and their alignment with SDG initiatives. On digital technologies relating to the Africa, Asia, and Pacific regions, the international Mobilizing Arab-Wide Action for Reliable Environmental Data (MAWARED) is an online platform allowing users to upload their environmental observations to a central server using smartphones. All observations are shown directly on an interactive web mapping system. The application promotes wellbeing and contributes to safety of cities, sustainable use of oceans, and the fight against desertification (SDGs 3, 11, 13, 14, 15, and 17). In Kenya, the Hydrologistics Africa Company developed the project HydroIQ, the world's first virtual water network operator, in line with SDGs 6, 9, and 11. HydroIQ is a smart metering device plugged into the existing water supply network, turning the traditional water system into a smart water grid. In Nigeria, the African Youth Movement, in partnership with Van Dijk Water Management B.V. Netherlands, initiated the program Nigeria Water Information System. The database tracks water loss through leakages as well as extortion, corrupt practices, and illegal connectivity. The messaging app has a user-friendly interface rural dwellers can use to send SMSs for broken pipes in the Bwari Area Council Territory. This project advances SDGs 1, 3, 9, 11, 13, and 14. The Ghana National Cleaner Production Centre implemented a project on electronic waste and developed the Ghana e-waste model that formed a basis for the 2016 Hazardous and Electronic Waste Control and Management Act. This led to the government setting up an e-waste recycling plant at Agbogbloshie. This project is instrumental in achieving SDGs 3, 6, 7, 8, 9, 11, 12, and 14 . 


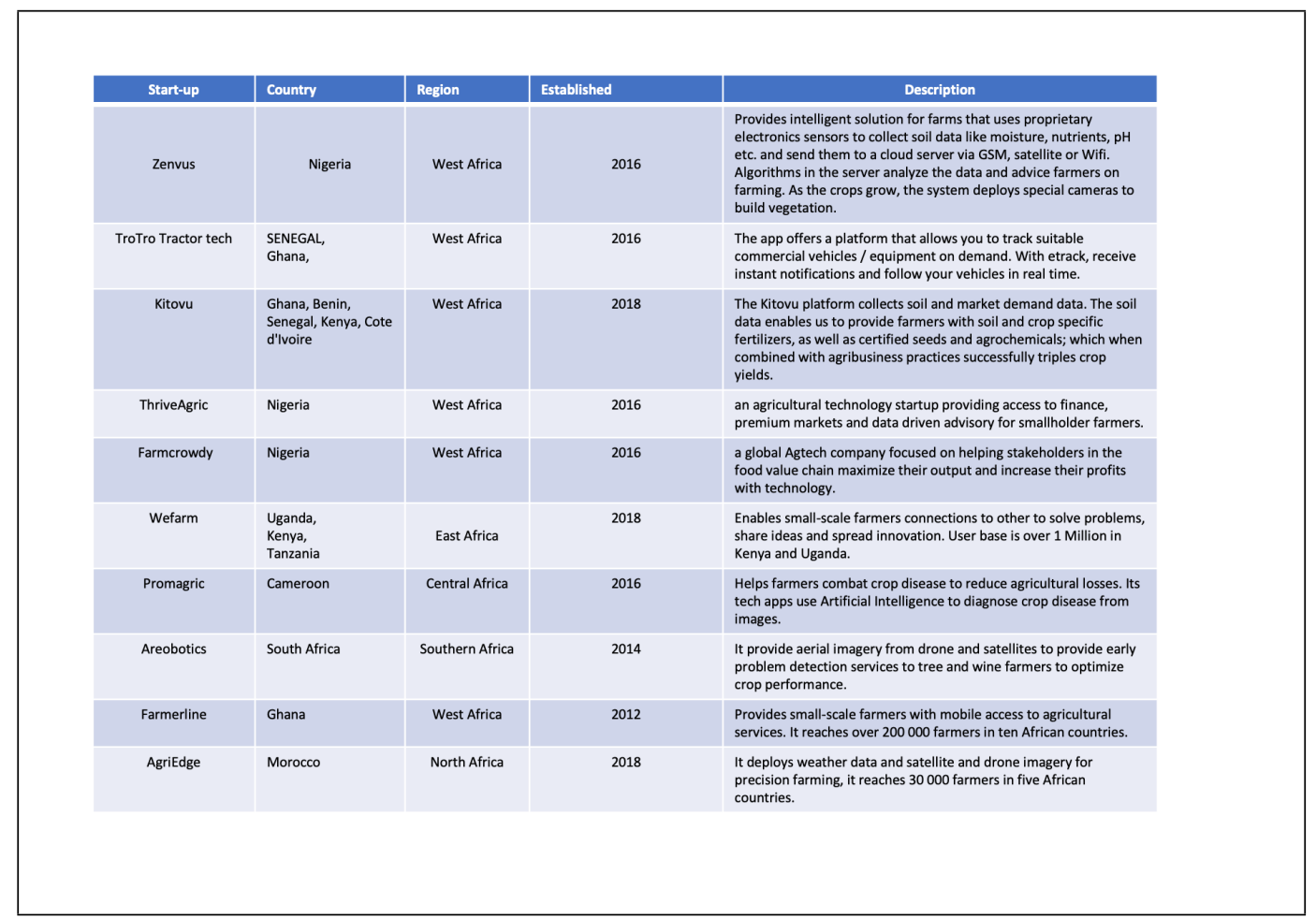

Source: Authors' Compilation

\section{Telecommunication and Infrastructure}

\section{Telecommunication}

Submarine cables and landing stations play an essential role in reducing the digital divide between Africa and the rest of the world. Previous connectivity across Africa was carried out through SAT3 cables. The continent's countries and players (operators, ISP providers) have, through satellite stations, over 70 submarine stations operated by 8 different consortiums/investors (SAT3, ACE, GLO, EASSY, SEACOM, WACS, MainOne, TEAMS). Africa connects directly with South America, offering alternative, lower-latency routes to the Americas through the South Atlantic Cable System (SACS). Cases include Hurricane Electric undersea cables into the Kenyan market by operating a point of presence in Nairobi, allowing service providers to buy international capacity (transit) from them directly without having to purchase both terrestrial and international transit. South Atlantic Cable System (SACS) are able to establish a point of presence by trading capacity on their international networks with African network operators (Song, 2020). Case projects include high-throughput satellites (HTSs) capable of delivering modern broadband speeds at realistic prices for ISPs. HTS launches in 2019, such as Spacecom's Amos 17 and Eutelsat's KonnectAfrica, have had real impact on the continent's rural Internet service delivery (Song, 2020;).

Additionally, licensed digital dividend spectrums (700MHz and $800 \mathrm{MHz})$ for mobile broadband have been realized across a number of African countries. In Ghana's $800 \mathrm{MHz}$ auction where MTN paid $\$ 67.5$ million for $20 \mathrm{MHz}(2 \times 10 \mathrm{MHz})$ of spectrum, Vodafone acquired $\$ 30$ million in spectrum for $10 \mathrm{MHz}$. In Tanzania, a successful spectrum auction was held in the $700 \mathrm{MHz}$ band, with two operators (Vodacom Tanzania and Azam Telecom) winning licenses for $20 \mathrm{MHz}(2 \mathrm{x} 10 \mathrm{MHz})$ for $\$ 10$ million each. In Mozambique, the regulator received bids for an $800 \mathrm{MHz}$ spectrum. Three of the five 
$10 \mathrm{MHz}(2 \times 5 \mathrm{MHz})$ lots were successfully auctioned at $\$ 15$ million to Mcel, Vodacom, and Movitel. In Kenya, the regulator has chosen not to use spectrum auctions; alternative plans for the $700 \mathrm{MHz}$ band saw the regulator divide the band into three lots $30 \mathrm{MHz}(2 \times 15 \mathrm{MHz})$. Jamii Telecom was given a trial license by the regulator, encouraging second-tier service providers to form consortia and pay a \$25 million fee. Cases for unlicensed and dynamic spectrum or television white spaces (TVWS) have seen several big leaps forward on the continent. In South Africa, regulators formally gazetted rules for the use of TVWS in the country. In Mozambique substantial moves were made toward TVWS regulation, partnering with Nominet, the UK internet registry that developed a TVWS geolocation database (Song, 2020;). These projects align with SDGs 4, 8,9, 12, and 17 (UNDP, 2017).

\section{Infrastructure}

ICT infrastructure, access, use, and skill have been implemented across African countries for over 30 years at a broadband infrastructure cost totaling over $\$ 5.5$ billion in investments. But the continent still lags behind the rest of the world, especially emerging Asian economies (WB, 2020b). Current mobile infrastructure, networks, and mobile devices are increasingly being used to access an array of life-enhancing services that contribute to and catalyse achievements related to SDG 9 (Industry, Innovation and Infrastructure), which remains the most impactful goal to spur inclusiveness, sustainable development, and greater innovation. In addition, mobile, with its half a billion unique mobile subscribers, has had an enormous impact on financial inclusion, cutting across multiple SDGs, including SDGs 1, 2, 3, 8, and 10. Four of the most populated markets in the region (D.R. Congo, Ethiopia, Nigeria, and Tanzania) will account for nearly half of the 115 million new subscribers expected by 2020 (WSIS and ITU, 2018 GSMA, 2017, 2020).

Infrastructure enablers have grown dynamically, fueled by expanded $4 \mathrm{G}$ coverage and mobile broadband coverage in Africa. Network quality has also improved substantially; the vast majority of countries now have average broadband speeds that allow reasonable-quality Internet browsing (greater than 2Mbps). Mobile Internet access, particularly for the poorest $20 \%$ of communities, experiences regional barriers, and while data has become more affordable, mobile devices remain out of reach with penetration rates at 45\%, much less than in other regions of the world (GSMA, 2020). In Benin, the ISOCEL initiative launched Cotonou's buggiest WiFi Network to deliver direct Internet connection to end users with WiFi-enabled devices. Meeting SDG targets will impact sustainable industrialization, inclusive and sustainable economic growth, employment and decent work for all, the building of resilient infrastructure, the development of inclusive, safe, resilient, and sustainable cities, and revitalization of the global partnership for sustainable development. In Cote d'Ivoire, the LIFI LED project enables access to high-speed Internet (3Gbps, 30 times faster than WiFi) taking the light from LED bulbs (renewable energy). The project is a green technology (ecological) project and promotes sustainable development as it uses visible light to transmit information rather than electromagnetic waves such as WiFi. It supports advancement of SDGs 1, 3, 4, 7, 10, 13, and 17. In Mali, operators implemented more than $6,000 \mathrm{~km}$ of optical fibre and the Government has installed over 3,000 km of optical fibre. This will allow the country to be connected in broadband with four of its seven neighbours - Burkina Faso, Cote d'Ivoire, Mauritania, and Senegal (SDGs 4, 8, 9, 12, and 17). Table 2. Examples of Digital starts-up, accelerators and Telecommunication \&Infrastructure layers forming the Africa's digital ecosystem, 2021.

Source: Adapted Crunchbase.com dataset- Replicated from OECD https://doi. org/10.1787/0a5c9314-en.

\section{Opportunities and Challenges: Frameworks, Models, and/ or Roadmap for Digital Transformation}

Realization of African countries' DT potential requires the continuation and reconfiguration of structural reforms, further innovation and investment, and widespread adoption of a digital ecosystem that gives rise to cluster technology providers and partnering organizations offering value chain 
International Journal of Digital Strategy, Governance, and Business Transformation

Volume $11 \cdot$ Issue 1

Table 3. African Digital Starts-Ups in Telecommunication and Infrastructure.

\begin{tabular}{|c|c|c|c|c|c|}
\hline \multicolumn{6}{|c|}{ Telecommunication and Infrastructure } \\
\hline Digital Impact & Company Name & Established Yr. & \begin{tabular}{|l|} 
Main Activity \\
\end{tabular} & $\begin{array}{l}\text { Location in } \\
\text { City }\end{array}$ & Country \\
\hline \multirow[t]{5}{*}{ Digital Economy } & OPay & 2018 & FinTech & Lagos & Nigeria \\
\hline & interswitch & 2002 & Fintech & Lagos & Nigeria \\
\hline & Cellulant & 2004 & Fintech & Nairobi & Kenya \\
\hline & Fawry & 2008 & Fintech & Cairo & Egypt \\
\hline & јUмо & 2014 & Fintech & Cape Town & South Africa \\
\hline \multirow[t]{6}{*}{ Digitalised economy } & M-KOPA & 2011 & Energy & Nairobi & Kenya \\
\hline & Twiga food & 2013 & Business-to-Business e-commerce & Nairobi & Kenya \\
\hline & Jumia Group & 2012 & E-commerce & Lagos & Nigeria \\
\hline & Kobo360 & 2018 & Logistics & Lagos & Nigeria \\
\hline & Takealot.com & 2011 & E-commerce & Cape Town & South Africa \\
\hline & Raye7 & 2016 & Ride Sharing & Cairo & Egypt \\
\hline \multirow[t]{3}{*}{ Start-up/accelerator } & Naspers & 1915 & ICT investment & Cape Town & South Arica \\
\hline & Co-Creation Hub & 2010 & Start-up incubation & Lagos & Nigeria \\
\hline & Flat6labs & 2011 & Early Stage Ventures and Seed funds & Cairo & Egypt \\
\hline \multirow[t]{6}{*}{ Core IT and Digital sector } & Sensor Networks & 2015 & Software and IT consulting & Cape Town & South Africa \\
\hline & Mara Phones & 2018 & Hardware Manufacturing & Kigali & Rwanda \\
\hline & Aerobotics & 2014 & Software and IT Consulting & Cape Town & South Africa \\
\hline & Orange & 1988 & Telecoms & Casablanca HQ & Morocco \\
\hline & MTN Group & 1994 & Telecoms & Johannesburg & South Africa \\
\hline & Safaricom & 1997 & Telecoms & Nairobi & Kenya \\
\hline
\end{tabular}

services: venture capital, mentoring, co-venturing, etc. Until these come into play, existing marginal contributions to the continent's digital ecosystem will remain. In this paper, the deployment of digital technologies have been broadly grouped into six substantive categories to determine optimization within the digital ecosystem, related market penetration, and transactions across African societies. The nexus of digital assets forming a part of the cluster organization are artificial intelligence, machine learning, Big Data, analytics, IoT, biotech, and nano- and microtech for satellite, health, 3D printing, and robotics, amongst other emerging digital technologies. Table 3. Examples, digital entrepreneurs forming the backbone to the African ecosystem.

Table 4. Entrepreneurs forming the backbone of African ecosystem.

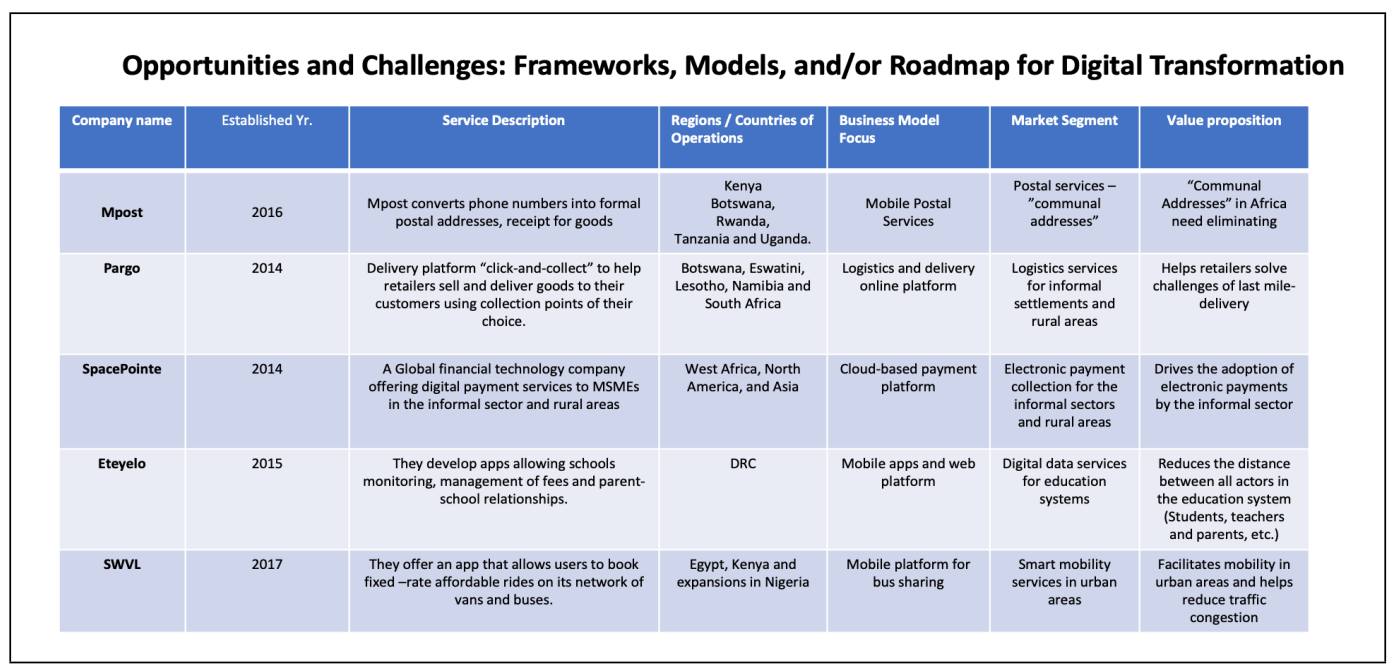


Source: OECD Africa's Development Dynamic2021; https://doi.org/10.1787/0a5c9314-en

To leverage the opportunities of digital technologies, international organizations have outlined specific plans of action for people, planet, and prosperity. These follow the UNDP 2030 Agenda, AfDB Group, and the African Union Development Agency-NEPAD (AUDA-NEPAD), incorporating the UN's SDGs, and AU Agenda 2063 along with those of nation states' Nationally Determined Contributions Plans, aligning with the Paris Agreement. Consideration of the UN's SDG agenda highlights the need to assist developing countries in attaining long-term debt sustainability through coordinated policies aimed at fostering debt financing, debt relief, debt restructuring, and sound debt management, as appropriate. Many countries remain vulnerable to previous debt crises (UNDP, 2017; WB, 2019c) and are now also in the midst of upheavals caused by the COVID-19 pandemic.

African countries are leveraging global research collaborations and partnerships such as with BFA Global to intersect critical sectors with technical cooperation. The case of Microsoft South Africa and Afrika Tikkun technical cooperation provided $\$ 150,000$ in grants to bring new digital skills to underserved populations and reskill workers impacted by COVID-19 (Andrews and de Montesquiou, 2021; Microsoft News Centre, 2021,AUC/OECD 2021). Regarding integrated planning in African countries, least-developed countries, landlocked developing countries, and small-island developing states build upon global, national, and regional level as well as the High-level Political Forum on sustainability development conferences and reviews of all relevant UN conferences and processes that promote regional economic integration and interconnectivity. All information is mapped to a partner online platform and serves as the main source of information access, knowledge, and experience for African countries, international agencies, and partners. The SDG index report (SDG Center for Africa and Sustainable Development Solutions Network, 2019) explains that nearly half of the 169 SDG targets are not quantified and only $40 \%$ of the indicators in the Global SDG framework have data. Some indicator data collection has not yet materialized, and some indicator methodology is still undefined. The data gaps are due to only four countries having managed to host a separate, standalone website for the SDGs: Gabon, Kenya, Morocco, and Nigeria. Botswana, Libya, Mauritius, Namibia, Uganda, and Zambia reported that an SDG web page exists on the coordinating ministry's website; in some of the countries, the data is particularly egregious. Out of all these countries, Botswana, Libya, and Nigeria are the only countries that update their SDG-related websites regularly. The common challenges are technical capacity, data collection and processing, and the adoption and application of international statistical standards and new technologies (SDG Center for Africa and Sustainable Development Solutions Network, 2019). African governments and regional agencies are formulating implementation strategies through environmental and cultural shifts to create space for international, regional, and locally available digital initiatives to work at achieving SDG goals.

\section{FINDINGS}

The paper finds that the digital technologies that align with SDG initiatives focus on items indicated in SDG 17: Strengthen the means of implementation and revitalize the global partnership for sustainable development through finance, technology, capacity building, trade, and systemic issues of policy and institutional coherence, multi-stakeholder partnerships, and data, monitoring, and accountability (GRI, UN Global Compact, and WBCSD, 2015). The eight substantive categories explain the progression of the digital landscape presented through multiple countries' and sectors' digital technology through case examples of deployment, experimentation, and implementation.

\section{CONCLUSION}

The landscape of activities faces policy constraints due to policies having differential implications for different stakeholders - African governments, the private sector in Africa, regional bodies in Africa, external agencies and NEP governments, and business partnerships underline that other social, 
political, or economic leverage and unofficial actions are detrimental to advancing the African digital agenda 2030 and 2065 priorities (EU-AU, 2018; OECD, 2020; UNCTAD, 2019). See Africa's key continental strategies/Programmes in Annex A1 and 2063 flagship programmes A2

\section{RESEARCH LIMITATIONS}

For this research, a decision was made to select articles, white papers, policy documents, roadmaps, and guidance notes pertaining to African DT. The implications are that the analysis synthesizes currently available literature. This also contributes towards the research study's limitations as previous articles may have provided additional information on parties' thoughts and ideas on the challenges in and opportunities for working towards advancing and fulfilling the SDG initiatives.

\section{PRACTICAL IMPLICATIONS}

Research with considerable content spanning multiple global institutions, partners, and agencies presents difficulties in accessing data and communication messages that provide consistency in understanding across all domains associated with the subject matter. Information and information access are further complications, and the verification procedure and next-level access are lengthy processes that also complicate the synthesis of primary research data. Non-familiarization with and the variation of organizations' search systems have additional practical implications.

\section{ORIGINALITY/VALUE}

Research spanning several years of enquiry and varied categories across multiple subjects from multiple global organizations can present difficulties in synthesizing the subject matter ideas. Here, the research is organized across categories and themes, resulting in a better understanding of the compiled effect of initiatives and the aligned goals that are to be achieved. This paper provides a framework for readers to determine the experiments, actions, and implementations of DT across the main economic pillars mentioned through the main documents underpinning research on this continent and subject domain. Manager in contributing firm, potential partners can use this knowledge on SDG guidance and objectives to achieve across digital Africa. 


\section{REFERENCES}

AfDB/OECD/UNDP. (2017). African Economic Outlook 2017: Entrepreneurship and Industrialisation. OECD Publishing. doi:10.1787/aeo-2017-

African Development Bank (AfDB). (2015). Tracking Africa's Progress in Figures 2014. https://www.afdb.org/ Tracking_Africa's_Progress_in_Figures.pdf

African Union (AU). (2015). Continental education strategy for Africa. https://au.int/sites/default/files/ newsevents/workingdocuments/27671-wd-continental_strategy_for_education_cesa_16-25_english_0.docx

African Union (AU). (2017). Harnessing the demographic dividend through investments in youth. https://au.int/ sites/default/files/documents/32665-doc-au-echo-magazine-2017-23june17-1.pdf

African Union (AU). (2020). The African Union (AU) Joins forces with HP INC to Expand Digital Learning Opportunities for African Youth. https://au.int/sites/default/files/pressreleases/38479-pr-pr_043_-_au_joins_ forces_with_hp_inc_to_expand_digital_learning_opportunities_for_african_youth.pdf

Andrews, C., \& de Montesquiou, A. (2021). The State of Economic Inclusion Report 2021. IBfR\&D and TWB.

Arnould, V., \& Strazzari, F. (2017). Institute for Security Studies (ISS). https://www.iss.europa.eu/sites/default/ files/EUISSFiles/Report_37_African\%20futures_0.pdfSSUE

Arntz, M., Gregory, T., \& Zierahn, U. (2016, June 16). The Risk of Automation for Jobs in OECD Countries. OECD Social, Employment, and Migration Working Papers, no. 189.

AUC/OECD. (2018). Africa's Development Dynamics 2018: Growth, Jobs and Inequalities. AUC, Addis. Ababa/ OECD Publishing. doi:10.1787/9789264302501-

AUC/OECD. (2021). Africa's Development Dynamics 2021: Digital Transformation for Quality Jobs. AUC, Addis Adaba/OECD Publishing. doi:10.1787/0a5c93114-

Auriacombe, C., \& Vyas-Doorgapersad, S. (2019). Critical considerations for the role of governments in the interface between good governance and sustainable development in developing countries. International Journal of Ebusiness and Egovernment Studies., 11(1), 1-15. doi:10.34111/ijebeg.20191111

Betchoo, N. K. (2017). Today's Challenge of Shaping E-learning in Sub-Saharan Africa. Asian Journal of Applied Science and Technology, 1(9), 92-94. http://ajast.net/volume-1-issue-9.html

BillariF.GiuntellaO.StellaL. (2017). Does broadband Internet affect fertility. IZA Institute of Labour Economics, Discussion Paper Series DP, No. 10935. https://ssrn.com/abstract=3029806

Choi, J., Dutz, M., \& Usman, Z. (2019). The future of work in Africa: Harnessing the potential of digital technologies for all. World Bank Group. https://openknowledge.worldbank.org/handle/10986/32124

Cummings, C., \& O'Neil, T. (2015). Do digital information and communications technologies increase the voice and influence of women and girls? A rapid review of the evidence. Overseas Development Institute. http://cdn. basw.co.uk/upload/basw_121940-10.pdf

Das \& Espinoza. (2019). Inclusion matters in Africa. https://openknowledge.worldbank.org/bitstream/ handle/10986/32528/IM-Africa.pdf?sequence $=1$

Demirgüç-Kunt, A., Klapper, L., Singer, D., Ansar, S., \& Hess, J. (2018). The Global Findex Database 2017: Measuring financial inclusion and the fintech revolution. The World Bank. https://documents.worldbank.org/ curated/en/332881525873182837/The-Global-Findex-Database-2017-Measuring-Financial-Inclusion-and-theFintech-Revolution

Department of International Relations and Cooperation (DIRCO). (2019). http://www.dirco.gov.za/

Dubus \& van Hove. (2017). M-PESA and financial inclusion in Kenya: Of paying comes saving? Academic Press.

Dutta, S., \& Lanvin, B. (2013). The Global Information Technology Report, Growth and Jobs in a Hyperconnected World.WEF. http://www3.weforum.org/docs/WEF_GITR_Report_2013.pdf 
Dutta, S., \& Bilbao-Osorio, B. (2012). The Global Information Technology Report 2012, Living in a Hyperconnected World. WEF. http://www3.weforum.org/docs/Global_IT_Report_2012.pdf

European Economic and Social Committee. (2017). Impact of digitalisation and the on-demand economy on labour markets and the consequences for employment and industrial relations. https://pmb.cereq.fr/doc_num. php?explnum_id=3830

Garbarino, E., \& Strahilevitz, M. (2004). Gender Differences in the Perceived Risk of Buying Online and the Effects of Receiving a Site Recommendation. Journal of Business Research, 57(7), 768-775. doi:10.1016/ S0148-2963(02)00363-6

Gates Foundation. (2017). Bill and Melinda Gates Foundation releases open-source software to support efforts that expand access to financial services in developing countries. https://www.gatesfoundation.org/Media-Center/ Press-Releases/2017/10/Bill-Melinda-Gates-FoundationReleases-Open-Source-Software-to-Expand-Access-toFinancial-Services

Global Education Monitoring Report Team. (2017). Accountability in education: Meeting our commitments; Global education monitoring report 2017/8. UNESCO Publishing. https://en.unesco.org/gem-report/report/2017/ accountability-education

GRI, UN Global Compact, \& WBCSD. (2015). https://sdgcompass.org/sdgs/sdg-17/

GSMA. (2013). The Mobile Economy 2013. https://www.gsma.com/newsroom/wp-content/uploads/2013/12/ GSMA-Mobile-Economy-2013.pdf

GSMA. (2016). The Mobile Economy Report 2016. https://www.gsma.com/gsmaeurope/gsma-europe-blog/ the-mobile-economy-report-2016/

GSMA. (2017). The Mobile Economy Sub-Saharan Africa 2017. https://www.gsma.com/subsaharanafrica/wpcontent/uploads/2018/11/2017-07-11-7bf3592e6d750144e58d9dcfac6adfab.pdf

GSMA. (2019, July 16). Youth population to drive strong subscriber growth across sub-Saharan Africa, finds new GSMA study. https://www.gsma.com/newsroom/press-release/youth-population-to-drive-strong-subscribergrowth-across-sub-saharan-africa/

GSMA. (2020). The Mobile Economy Sub-Saharan Africa 2020. https://www.gsma.com/mobileeconomy/wpcontent/uploads/2020/09/GSMA_MobileEconomy2020_SSA_Eng.pdf

Guislain, P. (2018). Africa-to-Africa Investment: A first look. https://www.afdb.org/fileadmin/uploads/afdb/ Documents/Generic-Documents/Africa-To-Africa_Investment-A_First_Look.pdf

Gürtzgen, N., Nolte, A., Pohlan, L., \& Van den Berg, G. (2018). Do Digital Information Technologies Help Unemployed Job Seekers Find a Job? Evidence from the Broadband Internet Expansion in Germany. IZA Institute of Labor Economics. www.iza.org

Hallward-Driemeier, M., \& Hasan, T. (2012). Empowering Women: Legal Rights and Opportunities in Africa. World Bank. https://openknowledge.worldbank.org/handle/10986/11960

Hanmer, L., \& Elefante, M. (2019). Achieving Universal Access to ID: Gender-based Legal Barriers Against Women and Good Practice Reforms. Washington, DC: World Bank License. https://openknowledge.worldbank. org/bitstream/handle/10986/32474/Achieving-Universal-Access-to-ID-Gender-based-Legal-Barriers-AgainstWomen-and-Good-Practice-Reforms.pdf?sequence $=1 \&$ isAllowed $=\mathrm{y}$

Hellström, J. (2010). The Innovative Use of Mobile Applications in East Africa. Sida Review 2010:12. Swedish International Development Cooperation Agency. https://www.sida.se/en/publications/the-innovative-use-ofmobile-applications-in-east-africa

Herrington, M., \& Kew, P. (2016). South African report 2015/16. Is South Africa heading for an economic meltdown? Global Entrepreneurship Monitor. https://www.gemconsortium.org/report/gem-south-africa-20152016-report

Herrington, M., \& Kew, P. (2017). Is there a change in attitude towards the small and medium business sector in South Africa? 2017/18. Global Entrepreneurship Monitor. https://www.gemconsortium.org/file/ open?fileId $=50411$ 
International Finance Corporation (IFC). (2019). Digital skills in sub-Saharan Africa. Spotlight on Ghana. International Finance Corporation. https://www.ifc.org/wps/wcm/connect/ed6362b3-aa34-42ac-ae9fc739904951b1/Digital+Skills_Final_WEB_5-7-19.pdf?MOD=AJPERES

International Labour Organization. (2018). Digital labour platforms and the future of work. Towards decent work in the online world. International Labour Organization. https://www.ilo.org/wcmsp5/groups/public/--dgreports/---dcomm/---publ/documents/publication/wcms_645337.pdf

International Telecommunication Union (ITU). (2017). Measuring the Information Society Report. https://www. itu.int/en/ITU-D/Statistics/Documents/publications/misr2017/MISR2017_Volume1.pdf

ITC \& WEF. (2019). Africa E-commerce agenda. Roadmap for action. International Trade Centre and World Economic Forum. http://www3.weforum.org/docs/WEF_Africa_EComm_EN.pdf

Kanwar, A., Balasubramanian, K., \& Carr, A. (2019). Changing the TVET paradigm: New models for lifelong learning. International Journal of Training Research, 17(S1), 54-68. 10.1080/14480220.2019.1629722

Kaup Lapõnin, K. (2018). E-governance challenges in Africa. https://icds.ee/e-governance-challenges-in-africa/

Laukkanen, T., \& Pasanen, M. (2008). Mobile banking innovators and early adopters: How they differ from other online users? Journal of Financial Services Marketing, 13(2), 2008. doi:10.1057/palgrave.fsm.4760077

Microsoft News Center. (2021). https://news.microsoft.com/en-xm/2021/04/28/making-south-africas-youthmore-employable-through-digital-skills-training/

Mobile Alliance for Maternal Action (MAMA). (n.d.). http://www.wrhi.ac.za/media/detail/mobile-alliance-formaternal-action-mama

Mundy, K., Green, A., Lingard, B., \& Verger, A. (Eds.). (2017). The handbook of global education policy. Wiley Blackwell.

OECD. (2017). Going Digital: Making the Transformation Work for Growth and Well-Being. Meeting of the OECD Councilat Ministerial Level, June 2017. https://www.oecd.org/mcm/documents/C-MIN-2017-4\%20EN.pdf

OECD. (2018). Bridging the digital gender divide. Include, upskill, innovate. Organisation for Economic Cooperation and Development. https://www.oecd.org/internet/bridging-the-digital-gender-divide.pdf

OECD. (2020, May 7). Policy Responses to Coronavirus (COVID-19). COVID-19 and Africa: Socio-economic implications and policy responses. https://www.oecd.org/coronavirus/policy-responses/covid-19-and-africasocio-economic-implications-and-policy-responses-96e1b282/

OECD and Africa. (2015). Active With Africa. https://www.oecd.org/global-relations/Active-with-Africa.pdf

Riquelme, H. E., \& Rios, R. E. (2010). The moderating effect of gender in the adoption of mobile banking. International Journal of Bank Marketing, 28(5), 328-341. doi:10.1108/02652321011064872

SDG Center for Africa and Sustainable Development Solutions Network. (2019). Africa SDG Index and Dashboards Report 2019. SDG Center for Africa and Sustainable Development Solutions Network. https:// sdgcafrica.org/wp-content/uploads/2019/06/SDGS_INDEX_REPORT_2019WEB.pdf

Song, S. (2020, January 3). African Telcoms Infrastructure in 2019. Many Possibilities. https://manypossibilities. net/2020/01/africa-telecoms-infrastructure-in-2019/

Starke-Meyerring, D. (2010). Globally networked learning environments: Reshaping the intersections of globalization and e-learning in higher education. E-Learning and Digital Media, 7(2), 127-132. doi:10.2304/ elea.2010.7.2.27

Stroetmann, K. (2018). Digital health ecosystem for African countries. A guide for public and private actors for establishing holistic digital health ecosystems in Africa. Federal Ministry for Economic Cooperation and Development. https://www.bmz.de/en/news/publications/publikationen-reihen/materialie345-digital-healthafrica-23694

Stroetmann, K. A. (2019). From Siloed Applications to National Digital Health Ecosystems: A Strategic Perspective for African Countries. In Improving Usability, Safety and Patient Outcomes with Health Information Technology (pp. 404-412). IOS Press. doi:10.3233/978-1-61499-951-5-404 
Tikly, L. (2019). Education for sustainable development in Africa: A critique of regional agendas. Asia Pacific Education Review, 20(2), 223-237. doi:10.1007/s12564-019-09600-5

Tor, A. (2017). Africa goes digital: Where and how? European Union Institute for Security Studies (EUISS). https://www.iss.europa.eu/sites/default/files/EUISSFiles/Alert_18_ICT_Africa.pdf

UNCTAD. (2019). Division on Investment and Enterprise: Results and Impact. Report 2019. United Nations Conference on Trade and Development (UNCTAD). https://unctad.org/system/files/official-document/ diae2019d2_en.pdf

UNCTAD. (2021). United Nations conference on trade and development (UNCTAD 2021). https://unctad.org/ system/files/official-document/gdsinf2021d1_en.pdf

UNDP. (2017, September 21). UNDP launches study on income inequality in sub-Saharan Africa. United Nations Development Programme. https://www.undp.org/content/undp/en/home/presscenter/pressreleases/2017/09/21/ undp-launches-study-on-income-inequality-in-sub-saharan-africa.html

UNFPA. (2018). Demographic Dividends Study Report 2018, Towards Maximising the Demographic Dividend in Namibia. https://namibia.unfpa.org/sites/default/files/pub-pdf/Namibia_Demographic_Dividend_Study_ Report_2018.pdf

UNICEF. (2010). Advocacy Toolkit: A guide to influencing decisions that improve children's lives. https://www. unicef.org/evaluation/files/Advocacy_Toolkit.pdf

UNICEF. (2019). Environment and Climate Change-Youth Climate Action. https://www.unicef.org/environmentand-climate-change

United Nations Economic Commission for Africa (UNECA). (2019). Fiscal Policy for Financing Sustainable Development in an Economic Report on Africa 2019. https://www.uneca.org/economic-report-africa-2019

United Nations Legal Identity Agenda Task Force. (2020). Overview of the United Nations Legal Identity Agenda. United Nations. https://unstats.un.org/unsd/statcom/51st-session/documents/BG-Item3k-Overview-E.pdf

WB. (2015). The Global opportunity in online outsourcing. https://documents.worldbank.org/curated/ en/138371468000900555/pdf/ACS14228-ESW-white-cover-P149016-Box391478B-PUBLIC-World-BankGlobal-OO-Study-WB-Rpt-FinalS.pdf

WB. (2019a). Achieving Africa's digital transformation is an ambition that requires game-changing cooperation. WB.

WB. (2019b). Executive Summary: Scaling up disruptive agriculture technologies in Africa. World Bank Group. https://olc.worldbank.org/content/executive-summary-scaling-disruptive-agricultural-technologies-africa

WB. (2019c). World Development Report 2019. The Changing Nature of Work. https://www.worldbank.org/ en/publication/wdr2019

WB. (2019d). Digital Development Partnership. Annual review 2018. Moving the Needle-Digital Technologies Becoming a Driver for Development. International Bank for Reconstruction and Development/The World Bank. https://pubdocs.worldbank.org/en/225781554301401135/DDP-Annual-Review-2018-Final-Web.pdf

WB. (2020a). COVID-19 (Coronavirus) drives sub-Saharan Africa toward first recession in 25 years. World Bank. https://www.worldbank.org/en/news/press-release/2020/04/09/covid-19-coronavirus-drives-sub-saharanafrica-toward-first-recession-in-25-years

WB. (2020b, October 8). World Bank Confirms Economic Downturn in Sub-Saharan Africa, Outlines Key Polices Needed for Recovery. World Bank. https://www.worldbank.org/en/news/press-release/2020/10/08/world-bankconfirms-economic-downturn-in-sub-saharan-africa-outlines-key-polices-needed-for-recovery

WEF. (2020). ICT COVID-19 Response: Partnering with Technology Companies to Combat COVID-19. http:// www3.weforum.org/docs/WEF_Tech_4_COVID_Early_Compendium_2020.pdf

WEF. (2021). Shifting Management and Leadership Roles in a Digital Age: An Analysis. Available from: https:// www.researchgate.net/publication/312926694_Shifting_Management_and_Leadership_Roles_in_a_Digital_ Age_An_Analysis 
World Bank Group. (2018, April 30). Republic of South Africa - Systematic country diagnostic. An incomplete transition. Overcoming the legacy of exclusion in South Africa. https://documents.worldbank.org/curated/ en/815401525706928690/pdf/WBG-South-Africa-Systematic-Country-Diagnostic-FINAL-for-board-SECPOEdit-05032018.pdf

World Development Report. (2019). The Changing Nature of Work. https://www.worldbank.org/en/publication/ wdr2019

World Economic Forum (WEF). (2016). Digital Transformation of Industries Demystifying Digital and Securing $\$ 100$ Trillion for Society and Industry by 2025. http://reports.weforum.org/digital-transformation/wp-content/ blogs.dir/94/mp/files/pages/files/wef-digital-transformation-2016-exec-summary.pdf

WSIS \& ITU. (2018). Regional WSIS stocktaking report 2016 - 2018. ICT projects and WSIS action line related activities in Africa. World Summit on the Information Society and International Telecommunication Union. https://www.itu.int/dms_pub/itu-s/opb/pol/S-POL-WSIS.REP_REG_AFR-2018-PDF-E.pdf 
International Journal of Digital Strategy, Governance, and Business Transformation Volume $11 \cdot$ Issue 1

\section{APPENDIX A - AFRICA'S KEY CONTINENTAL STRATEGIES/PROGRAMMES (1)}

Table 5. Africa Digital Transformation Strategy alignment to SDG2030 \& Goals 2065

\section{Annex A1. Africa's key continental strategies/Programmes (1)}

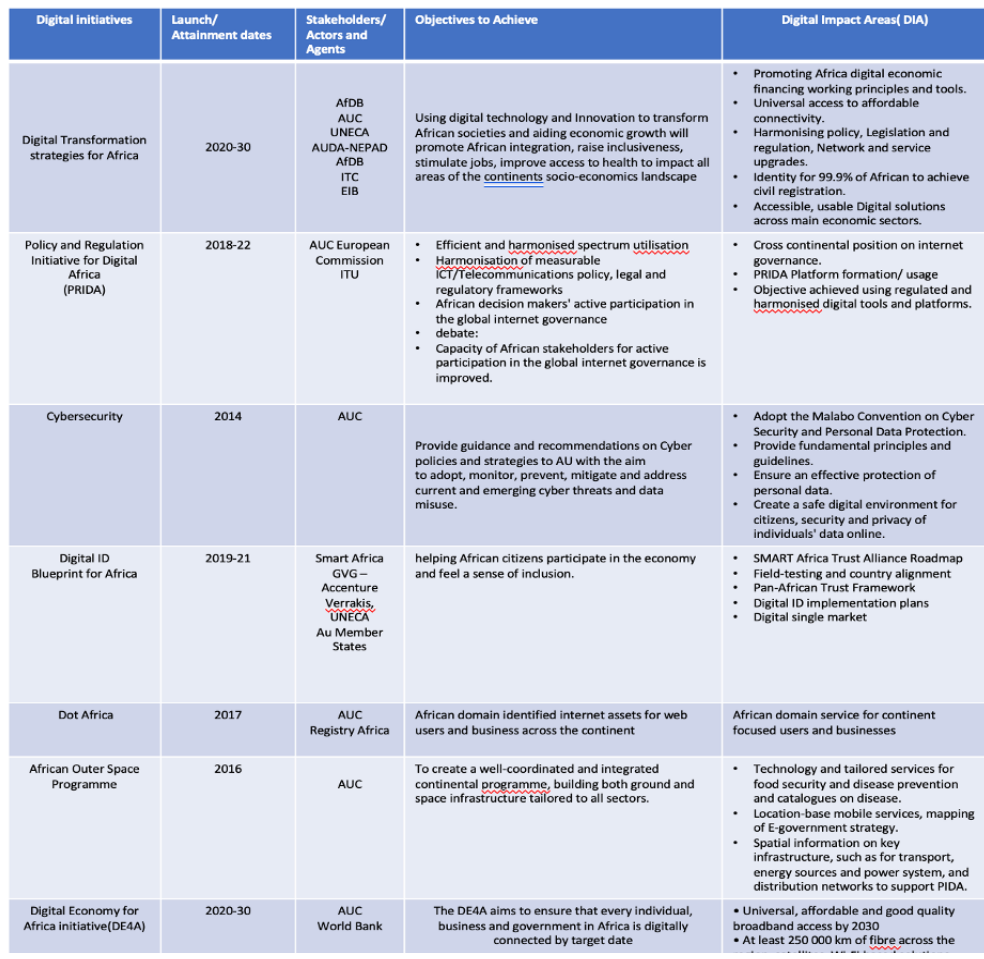

Source: UNESCWA.org-LAS joint workshop on Developing the African digital agenda. 


\section{APPENDIX B - AU AGENDA 2063 FLAGSHIP PROGRAMMES \\ (2) AND PRIORITY PROGRAMMES CONTRIBUTING TO \\ DIGITALISATION AND JOB CREATION IN AFRICA}

Table 6. AU Agenda 2063 flagship and priority programmes for African digital job creation.

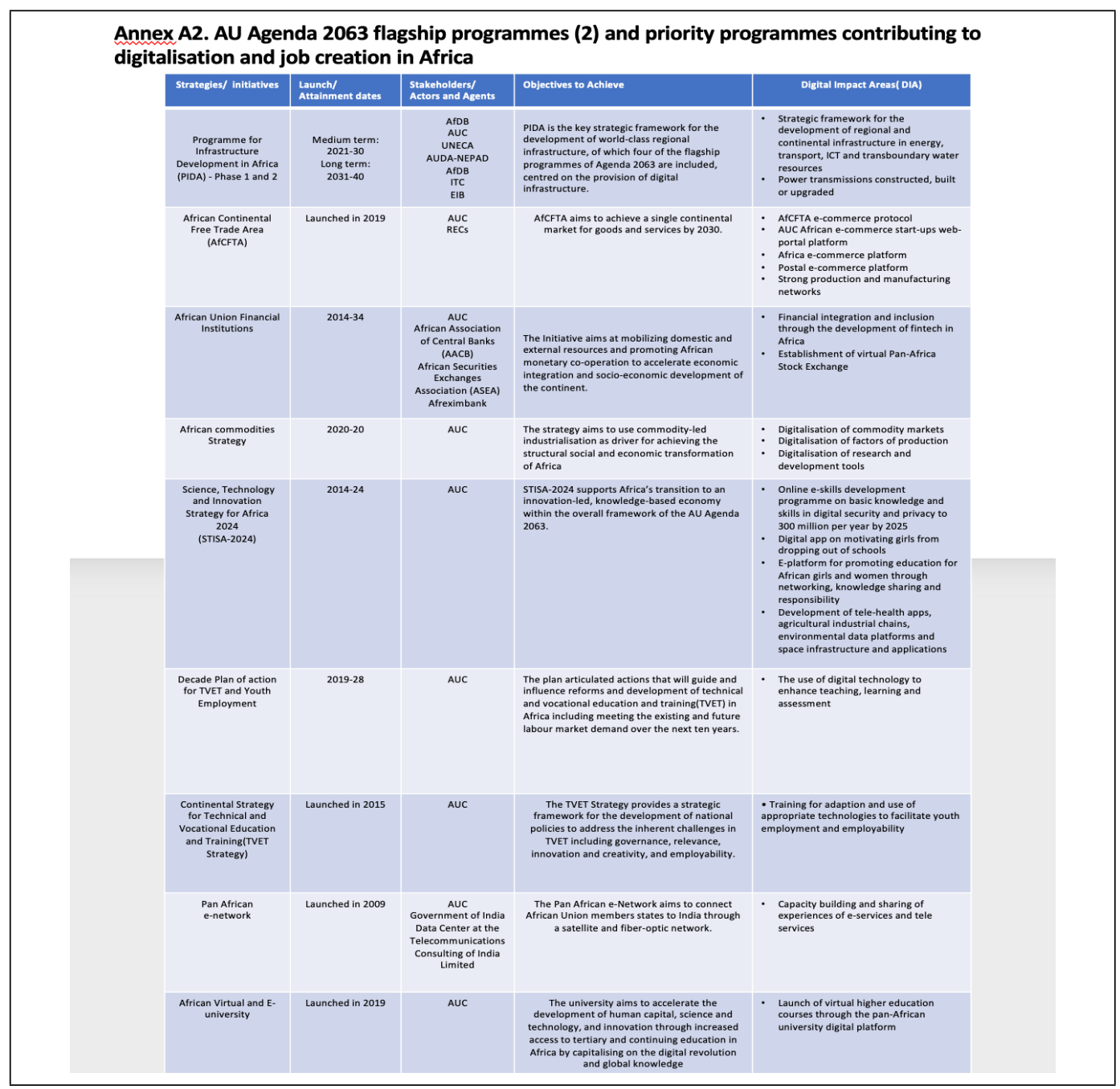

Source: OECD Africa's Development Dynamic 2021

Fouad Kazim specialises in Digital Transformation \& Leadership. He solves complex business and social challenges using digital assets. 